\title{
Os memes em pauta: uma análise discursiva das apropriações midiáticas do humor ${ }^{1}$
}

Memes on the agenda: a discourse analysis of media appropriations of humor

Los memes en la agenda: un análisis discursivo de las apropiaciones mediáticas del humor

DOI: https://doi.org/10.1590/1809-58442021111

Tássia Aguiar de Souza ${ }^{1}$

https://orcid.org/0000-0002-1823-2120

Mateus Yuri Passos ${ }^{1}$

https://orcid.org/0000-0003-0707-0135

${ }_{1}^{1}$ (Universidade Metodista de São Paulo, Programa de Pós-Graduação em Comunicação Social. São Bernardo do Campo - SP, Brasil).

\section{Resumo}

Estudo sobre a penetração dos memes políticos de discussão pública na mídia hegemônica a partir da repercussão dos memes sobre a prisão do ex-presidente Lula nos websites El País (edição brasileira) e Estadão. A pesquisa tem por objetivo analisar a presença destes na agenda midiática e suas apropriações discursivas no contexto de crise política no Brasil. Para tal, tomamos como referencial teórico o conceito de semiosfera, de Iuri Lótman; a proposta do Homo Narrans desenvolvida por Alain Rabatel; e, ainda, as funções políticas dos memes de internet propostas por Limor Shifman. A metodologia empregada constitui-se de uma análise discursiva dos memes selecionados pelos veículos indicados acima. Resulta, desta pesquisa, a reflexão sobre o uso dos memes de internet não apenas como mero entretenimento, mas como instrumentos de ativismo político e discurso informativo.

Palavras-chave: Discurso. Memes. Mídia Hegemônica. Política.

\section{Abstract}

This paper presents a study on the penetration of public discussion political memes in the hegemonic media based on the repercussion of memes about the arrest of former Brazilian President Lula on the websites El País (Brazilian Edition) and Estadão. The research aims to analyze the presence of memes in the media agenda and the appropriations of their discourses related to the political crisis

1 Uma versão anterior deste artigo foi apresentada no I Encontro Norte e Nordeste da ABCiber no GT3 - Comunicação, Mídia e Poder no Ciberespaço. O presente trabalho foi realizado com apoio do Conselho Nacional de Desenvolvimento Científico e Tecnológico (CNPq) - Brasil. 
in Brazil. For this, we take as a theoretical reference the concept of semiosphere, by Iuri Lótman; the notion of Homo Narrans developed by Alain Rabatel; and yet, the political functions of internet memes as proposed by Limor Shifman. The methodology consists of a discourse analysis of memes reproduced in the two websites mentioned. The result of this research is the reflection on the use of internet memes not only as mere entertainment, but as instruments of political activism and informative discourse.

Keywords: Discourse. Memes. Mainstream media. Politics.

\section{Resumén}

El artículo presenta un estudio sobre la penetración de memes políticos de discusión pública en los medios hegemónicos a partir de la repercusión de los memes sobre la detención del expresidente de Brasil Lula en los sitios web de El País (edición brasileira) y Estadão. La investigación tiene como objetivo analizar su presencia en la agenda mediática y sus apropiaciones discursivas en el contexto de la crisis política en Brasil. Para ello, tomamos como referencia teórica el concepto de semiosfera, de Iuri Lótman; la propuesta de Homo Narrans desarrollada por Alain Rabatel; y, sin embargo, las funciones políticas de los memes de Internet propuestas por Limor Shifman. La metodología utilizada consiste en un análisis discursivo de los memes seleccionados por los vehículos indicados anteriormente. El resultado de esta investigación es la reflexión sobre el uso de los memes de Internet no solo como mero entretenimiento, sino como instrumentos de activismo político y discurso informativo.

Palavras clave: Discurso. Memes. Medios hegemónicos. Política.

\section{Introdução}

O uso do humor nos discursos contra-hegemônicos em tempos de crise no Brasil não é um fenômeno novo. Temos como exemplo emblemático, na década de 1970, o caso d’O Pasquim, que materializava suas críticas ao Regime Militar a partir da ironia e do escracho cômico às figuras detentoras do poder e, apesar da proposta inicial de ser um semanário humorístico de tiragem modesta, manteve-se em circulação por 22 anos, resistindo a constantes investidas repressivas, e tornou-se um grande fenômeno na história da mídia alternativa no país. A utilização do humor como instrumento contra-hegemônico no Brasil é tão expressiva que essa prática vem sendo alvo de sucessivos ataques por parte de personalidades políticas em tempos de crise e de eleições. Entre os episódios recentes, tivemos a promulgação de uma lei eleitoral, durante as eleições presidenciais de 2010, que proibia humoristas de usarem os candidatos como alvo de piadas. O STF, porém, suspendeu a lei, em agosto do mesmo ano, a pedido da Associação Brasileira de Emissoras de Rádio e Televisão (Abert).

Na Era Digital, com a participação dos usuários na produção de conteúdo, um modelo discursivo nos chama a atenção: os memes de internet. Shifman (2014) definiu os memes políticos de discussão pública como aqueles de origem amadora, atravessados pelo humor/ ironia e com finalidade crítica. A visibilidade que os memes políticos ganharam no Brasil 
desde as eleições presidenciais de 2014 vem transformando esse instrumento - em princípio, de entretenimento - em ferramenta de ativismo político na esfera pública. Acreditamos que o uso do humor, inicialmente designado com o intuito de angariar cliques, encoraja o compartilhamento das publicações, que são ressignificadas a partir de cada usuário e ganham forma de posicionamento político em perfis individuais e na imprensa, chegando novamente a influenciar decisões políticas, como verificou-se em 2018 na tentativa do governo federal em controlar o uso de fotografias oficiais do então presidente Michel Temer na produção de memes em perfis de humor na internet.

Em âmbito global, Castells (2013) - em Redes de Indignação e Esperança - retratou bem a ampliação de efeitos sociais causados pela mídia em decorrência do acelerado desenvolvimento de sistemas e tecnologias que permitem a quebra de fronteiras geográficas e culturais e viabilizam a distribuição de conteúdo a baixo custo e em tempo real. Por se tratar de uma criação contemporânea e dada a relevante influência dos memes no cotidiano dos brasileiros, sobretudo em meio à crise política que atravessa o país, consideramos relevante a investigação sobre como essa manifestação tem penetrado a pauta da mídia mainstream e consequentemente o debate político no país. Justifica, ainda, ampliarmos a investigação sobre a apropriação e possível ressignificação desses discursos nos veículos tradicionais.

Nesse contexto, selecionamos para esta análise, a cobertura da prisão do ex-presidente Lula, no dia 7 de abril de 2018, que contou com a pauta dos memes políticos de discussão pública em diversos veículos digitais, tais como o El País, O Estadão, Istoé, IG, Terra, Uol, O Estado de Minas etc. Segundo Souza (2019), a prisão do ex-presidente Lula aparece entre os principais temas pautados pela mídia sob a ótica dos memes, entre julho de 2018 e janeiro de 2019.

Acreditamos que a escolha dos memes em cada veículo obedece a uma linha editorial parcial e pretendemos demonstrar, por meio de análise discursiva, essa tendência em três publicações de dois veículos: El País e Estadão, dada a abrangência e suposta dualidade editorial dos dois periódicos. Para tal, trabalharemos com a proposta de Alain Rabatel de descentramento da narrativa para a narração, como forma de asseverar as escolhas do enunciador em questão.

\section{A memética e os memes de internet}

Em 1976, o biólogo evolucionista Richard Dawkins cunhou o termo que daria origem a um campo de estudos multidisciplinar: a ciência memética. O conceito inicial de meme proposto por Dawkins em 1976 no livro O gene egoísta buscava compreender o fenômeno de replicação de características genéticas entre os organismos, assim como os demais eventos culturais que repetiam esse processo de compartilhamento de informações entre indivíduos.

Entendido no senso comum como algo que se espalha rapidamente na internet ou que é amplamente imitado de forma humorística, o termo meme é uma abreviação da palavra grega mimetes (imitação) e, segundo o autor, pode ser aplicado a: 
melodias, ideias, "slogans", modas do vestuário, maneiras de fazer potes ou de construir arcos. Da mesma forma como os genes se propagam no "fundo" pulando de corpo para corpo através dos espermatozoides ou dos óvulos, da mesma maneira os memes propagam-se no 'memepool' pulando de cérebro para cérebro por meio de um processo que pode ser chamado, no sentido amplo, de imitação. Se um cientista ouve ou lê uma ideia boa ele a transmite a seus colegas e alunos. Ele a menciona em seus artigos e conferências. Se a ideia pegar, pode-se dizer que ela se propaga (...) espalhando-se de cérebro a cérebro (DAWKINS, 2007, p. 122).

No entanto, Dawkins sustenta que o potencial replicador dos memes está inserido neles próprios a partir de três características fundamentais: longevidade, fecundidade e fidelidade.

Com a popularização dos memes de internet, a investigação sobre o fenômeno da replicabilidade ganha o campo da Comunicação e a ideia dessas três chaves propostas por Dawkins é questionada por Chagas e Toth (2016), por exemplo, que acreditam que elas limitam a análise dos memes à forma como a mensagem se propaga, ignorando que mensagem é esta e por que ela é propagada. O autor compreende os memes como construções culturais que se articulam e são difundidos por agentes humanos e/ou grupos organizados - e, conforme observaremos, o componente do humor nem sempre estará presente.

Isto é, não há um poder “misterioso” dos memes em si - como supunha Blackmore (2000) - que impulsiona os processos de difusão cultural, mas teias de significados construídas pelas pessoas em torno deles. Acima de tudo, reforça-se o entendimento de Shifman (2014) sobre a necessidade de avaliarmos os memes não como unidades de conteúdo isoladamente apreensíveis, mas como conjunto semântico, coleção, sem o qual não é possível alcançar seu significado (CHAGAS, 2017, p. 184).

Há ainda, nas pesquisas em Comunicação, um notável esforço na proposição de taxonomias que facilitem as investigações sobre esses replicadores. Entre as propostas de classificação conhecidas dos memes de internet, nos interessa neste trabalho a da jornalista e pesquisadora israelense Shifman (2014), citada por Chagas, de uma função dos memes como forma de participação política. Segundo ela, esses memes podem ser classificados como (1) memes de persuasão; (2) memes de ação coletiva; e (3) memes de discussão pública. Os memes de persuasão são aqueles produzidos e compartilhados por personalidades ou organizações políticas com o intuito de propagar uma ideia ou evento. No geral, possuem formatação profissional e cabe aos usuários o compartilhamento sem interferência no conteúdo. Nesta categoria, o humor é dispensável. Da mesma forma, os memes de ação coletiva são reproduzidos massivamente pelos usuários em sua forma original, porém, não são necessariamente orquestrados por organizações políticas, tampouco estão condicionados 
à apropriação humorística, e podem ser materializados também em ações como o desafio do balde de gelo².

Já os memes de discussão pública são aqueles que nascem exclusivamente dos usuários da rede, reforçando o modelo participativo da web 2.0. Neste modelo, as peças costumam ser amadoras e podem ser compostas no formato de texto verbal, imagem, gif, vídeo e/ou a combinação de duas ou mais destas formas. A crítica política e provocação do riso são elementos indispensáveis nos memes de discussão pública e o compartilhamento das peças conta com a interferência de cada usuário em seu conteúdo.

Apesar da autora focar sua proposta taxonômica na forma e no conteúdo dos memes na obra em questão - para Chagas (2017), existe um potencial nessa classificação funcional que ultrapassa a organização proposta por Shifman (2014). Em estudo sobre os usos e as apropriações de memes político-eleitorais em circulação durante os debates presidenciais de 2014, o autor propôs subcategorias a cada uma das funções propostas pela autora israelense que levam em conta a retórica e o seu apelo; as dinâmicas de ação coletiva nas mídias sociais e como influenciadores de comportamentos; e o tipo de mensagem apresentada, qualificando os conteúdos de acordo com o objeto do humor.

Uma vez que apenas os memes de discussão pública são o objeto deste trabalho, seguiremos com a proposta das subcategorias relacionadas a eles. São elas: (1) Lugarescomuns da política: conteúdos que apresentem comentários sobre a corrida eleitoral como guerra, a luta contra o comunismo, os políticos como corruptos etc; (2) Alusões literárias ou culturais: conteúdos que apresentem menções a produtos culturais (séries, filmes etc.) ou à cultura popular em geral, incluindo referências a personagens famosos e assim por diante; (3) Piadas sobre personagens da política: conteúdos que apresentem comentários sobre personagens específicos da cena política; e (4) Piadas situacionais: conteúdos que apresentem comentários sobre reações, expressões faciais, gestuais ou corporais dos candidatos em determinadas situações.

2 O Desafio do Balde de Gelo foi lançado em 2014 pela ALS Association para arrecadar dinheiro para pesquisas sobre a esclerose lateral amiotrófica (ELA). Cada pessoa que doasse para a campanha deveria gravar um vídeo virando um balde de água gelada na cabeça e desafiando três amigos a fazer o mesmo. A adesão de celebridades como Bill Gates, Mark Zuckerberg Taylor Swift, Neymar, Gisele Bündchen e Ivete Sangalo ao desafio foi essencial para o sucesso da campanha, que logo viralizou nas redes e arrecadou mais de 100 milhões de dólares. Fonte: Revista Veja. 
Quadro 1 - Exemplos de memes classificados por sua função política com base em Shifman (2014)

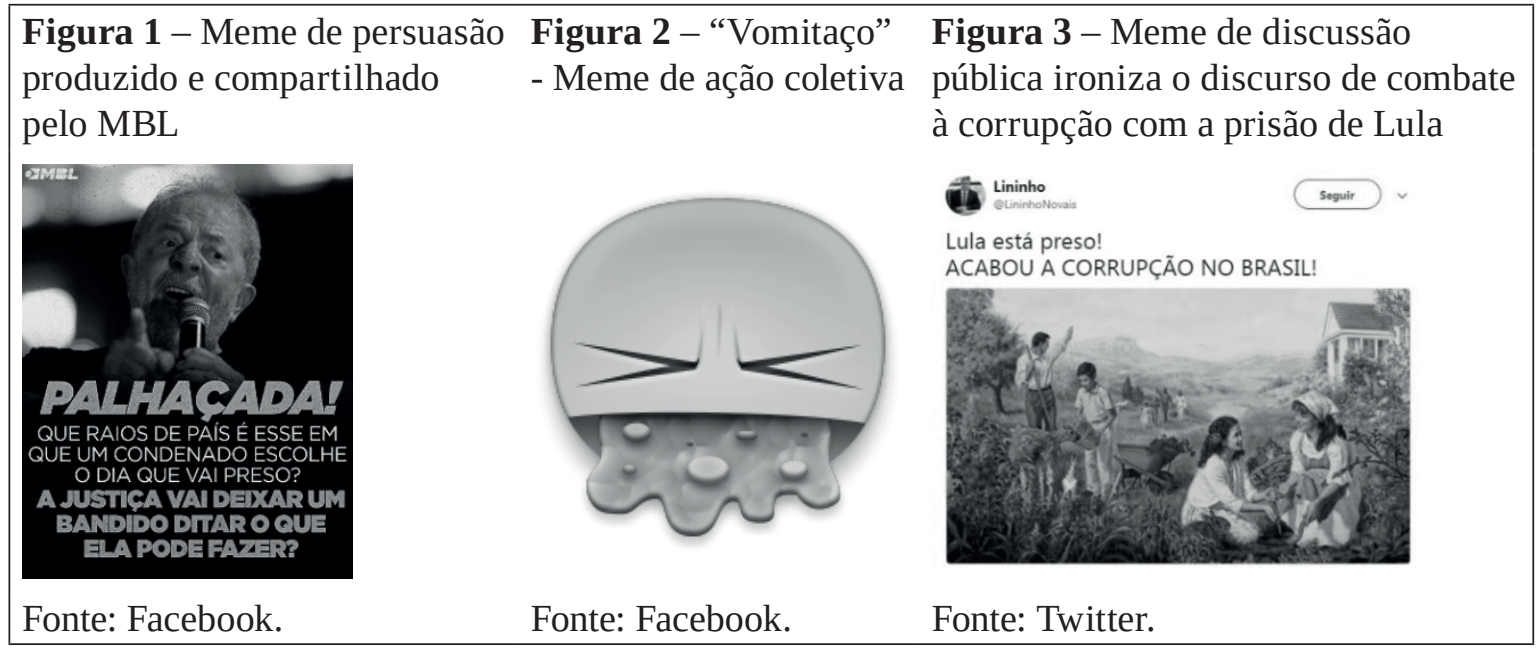

Fonte: autores.

\section{Apropriação midiática}

Como adiantamos, o sucesso dos memes de internet pode ser percebido também em sua apropriação pelos discursos jornalísticos e publicitários. Casos já repercutidos em pesquisas acadêmicas, como o da fanpage da Prefeitura de Curitiba no Facebook que aproveitou o potencial dos memes para sua comunicação institucional nas redes sociais no início da década, ainda são repetidos. A provedora de filmes e séries de TV via streaming, Netflix, por exemplo, também tem se apropriado dessa nova linguagem: personagens meméticas como Inês Brasil, Gretchen e Xuxa foram protagonistas dos vídeos de divulgação, no Brasil, de três de suas recentes produções: Orange Is The New Black, Glow e Stranger Things, respectivamente.

No campo jornalístico, veículos tradicionais em plataforma digital também estão atentos à pauta dos memes: El País, BBC, Estadão e New York Times são exemplos de publicações que já pautaram a “zoeira” dos brasileiros na internet. Sobre o assunto, sugerimos, em 2017, uma compreensão dessa apropriação da mídia hegemônica pelos memes de internet a partir do conceito de Semiosfera de Lótman (1996). O trabalho intitulado "Memes e contracultura: a reconfiguração de narrativas hegemônicas na semiosfera” (SOUZA, 2017) analisa o movimento de resistência dos produtores de memes que reconfiguram discursos midiáticos nas redes sociais e os devolvem aos veículos tradicionais em pautas humorísticas.

A Semiosfera, que contempla toda forma de cultura, constitui-se de sistemas sígnicos compostos de núcleos e periferias. "A cultura situada no núcleo desse sistema representa aquela de maior influência e controle sobre as demais manifestações, enquanto que a cultura periférica desenvolve-se às margens do sistema, mas sempre em contato com o 
centro hegemônico” (SOUZA, 2017, p. 59). Assim, propusemos a localização dos memes na periferia da semiosfera, onde ele se apropria de notícias e conceitos sedimentados nos discursos tradicionais da mídia e de instituições políticas transformando-os em escárnio e expondo as vozes dominantes ao contraditório e ao ridículo.

Evidenciamos assim o caráter contestador por trás dos memes de discussão pública às forças dominantes historicamente configuradas e sua capacidade de penetração em espaços privilegiados de fala. Em consonância, Chagas (2017) entende ser equivocada a compreensão do fenômeno dos memes como "cultura inútil” ou "besteirol” e atribui o equívoco, em parte, à ausência de estudos que se debrucem sobre o universo polissêmico dos memes e das apropriações dessas produções em contextos reconhecidamente políticos.

Nessa esteira, Milner (2017) acredita que, mesmo com as limitações próprias do acesso à tecnologia, nossas “conversas públicas” são mais ressonantes do que nunca.

Ao amplificar essas vozes, os meios meméticos evidenciam a criatividade e a contribuição que nos afastam ainda mais dos simples entendimentos "de cima para baixo” da influência da mídia. O mundo da mídia participativa é criado - trazido à existência e sustentado - através de inter-relações meméticas confusas. Existe no espaço entre textos individuais e conversas mais amplas, entre cidadãos individuais e discursos culturais mais amplos (MILNER, 2016, on-line - Tradução nossa).

Porém, ao apropriar-se dos discursos polifônicos do ambiente digital, essas vozes são reconfiguradas pela mídia hegemônica e esboçam um movimento de retomada da influência vertical. Nosso objetivo com esta proposição não é contestar a certa participação dos memes no debate público, mas investigar que uso os veículos tradicionais têm feito da popularidade e pluralidade discursiva desses memes e a instrumentalização de suas táticas subversivas na semiosfera.

\section{Apropriação discursiva}

Mas o discurso é também dialógico porque quando falamos ou escrevemos, dialogamos com outros discursos, trazendo a fala do outro para o nosso discurso. Isso se faz de forma explícita usando, por ex., o discurso direto, indireto, indireto livre ou colocando palavras, enunciados (do outro) entre aspas ou itálico (BRANDÃO, s/d).

Para contemplarmos uma dimensão antropológica e de certa forma engajada na atividade do narrar, fundamentamos esta pesquisa também no conceito de Homo narrans que Rabatel (2016, p. 15) propõe como alternativa a uma narratologia essencialmente estruturalista cedendo espaço às "paixões, às emoções e às sensações, por intermédio da 
atenção dada às questões entrecruzadas das vozes e dos pontos de vista, dos valores e da estética”, com foco nas escolhas que o escritor opera. Portanto, temos o descentramento teórico da narrativa para o narrador.

Nesse contexto, a hipótese de que as escolhas dos memes deveriam justificarse no perfil editorial de cada veículo comprova-se como veremos nas análises a seguir. O posicionamento velado pelo entretenimento manifesta-se em vozes que são apropriadas pelos veículos e tornam-se objeto de engajamento.

Para a execução deste exame, propomos um protocolo de análise com os direcionamentos descritos no quadro abaixo:

Quadro 2 - Protocolo de Análise

\begin{tabular}{|l|l|}
\hline \multirow{2}{*}{ Foco do chiste } & $\begin{array}{l}\text { Lugares comuns na política; } \\
\text { Piadas sobre personagens da política; } \\
\text { Alusões literárias ou culturais; } \\
\text { Piadas situacionais. }\end{array}$ \\
\hline \multirow{2}{*}{$\begin{array}{l}\text { Imagem do ex- } \\
\text { presidente Lula }\end{array}$} & Posição da imagem na matéria \\
\cline { 2 - 2 } & Expressões/gestos do ex-presidente \\
\cline { 2 - 2 } & Cenário/Ocasião \\
\hline \multirow{2}{*}{ Outros personagens } & Personagens ficcionais \\
\cline { 2 - 2 } & Adversários políticos do ex-presidente: qual é o tratamento dado a eles? \\
\hline Tipo de humor & Espiritual ou satírico? \\
\hline
\end{tabular}

Fonte: autores.

O protocolo emergiu da análise prévia dos memes selecionados pelos veículos para as referidas publicações. Trata-se das características mais evidentes dadas aos diversos personagens e situações e, uma vez relacionadas, buscam evidenciar as tendências discursivas de cada veículo.

Além das subcategorias dos memes de discussão pública apresentadas por Chagas (2017) para orientar o enfoque dado aos memes, recorremos também ao recurso estético do humor. Lançamos mão do diagrama proposto pelo esteta francês Étienne Souriau com 24 categorias estéticas apresentadas por Silva (2010, p. 90):

As categorias estéticas resultam de um esforço compendiário em torno da presença de traços recorrentes, de convenções de gênero, dados estilísticoformais e de configurações de relações afetivas entre objetos e público. Elas são combinatórias organizadas, um sistema relativamente coerente de exigências para que certa composição artística ou extra-artística alcance um determinado gênero. 
Na proposta de Souriau, seis categorias estéticas correspondem a estímulos provocadores do riso (humor): espiritual, satírico, cômico, irônico, caricatural e grotesco. No corpus levantado para esta investigação ora destaca-se o humor espiritual, ora o satírico. O espiritual corresponde a um riso contido, por meio de uma crítica branda. Para Silva (2010, p. 101), “o objeto é tratado de tal modo que não suma por completo ante a desvalorização; fazendo, assim que se preserve alguma atração ou simpatia por ele (...) e com ele estabelecemos certa afinidade, cumplicidade”. Já no humor satírico, o objeto é rebaixado à sua nulidade, até que se perca toda simpatia por ele. O riso provocado é desprovido de ternura e advém da indignação.

\section{Resultados}

A reportagem do El País publicada no dia 7 de abril com o título "Lula preso, memes à solta”3 traz como primeiro meme de sua seleção, um caso evidente de piada situacional, uma montagem do ex-presidente Lula em depoimento ao juiz Sérgio Moro trajando a camisa do São Paulo, time de futebol paulista (Figura 4). Visto que o ex-presidente já manifestou publicamente sua torcida pelo time adversário, Corinthians, e que o São Paulo não conquista um título nacional há 10 anos, a montagem faz referência a uma suposta tentativa do expresidente de provar ao juiz Sérgio Moro que "há 10 anos não ganha nada”. Porém, o parágrafo da matéria que se refere a este meme diz que o jejum de títulos nacionais do São Paulo “foi usado para ironizar o mandado de prisão expedido pelo juiz Sérgio Moro”. O meme que já deslocava a crítica para o time paulista, recebe um reforço do veículo no desvio de seu alvo e atinge o responsável pela prisão de Lula. Além disso, a posição privilegiada e repetida - a imagem é destaque e primeira ilustração da reportagem - de um meme que não faz crítica direta à figura do ex-presidente, mas do time de futebol e/ou ao juiz Sérgio Moro dá o tom de uma matéria de crítica leve a Lula e uma possível tendência a expor seu algoz, criticando a prisão e não o prisioneiro.

3 Disponível em: https://brasil.elpais.com/brasil/2018/04/06/politica/1523046165_909738.html. Acesso em: 4 jun. 2018. 
Quadro 3 - Seleção de memes do El País

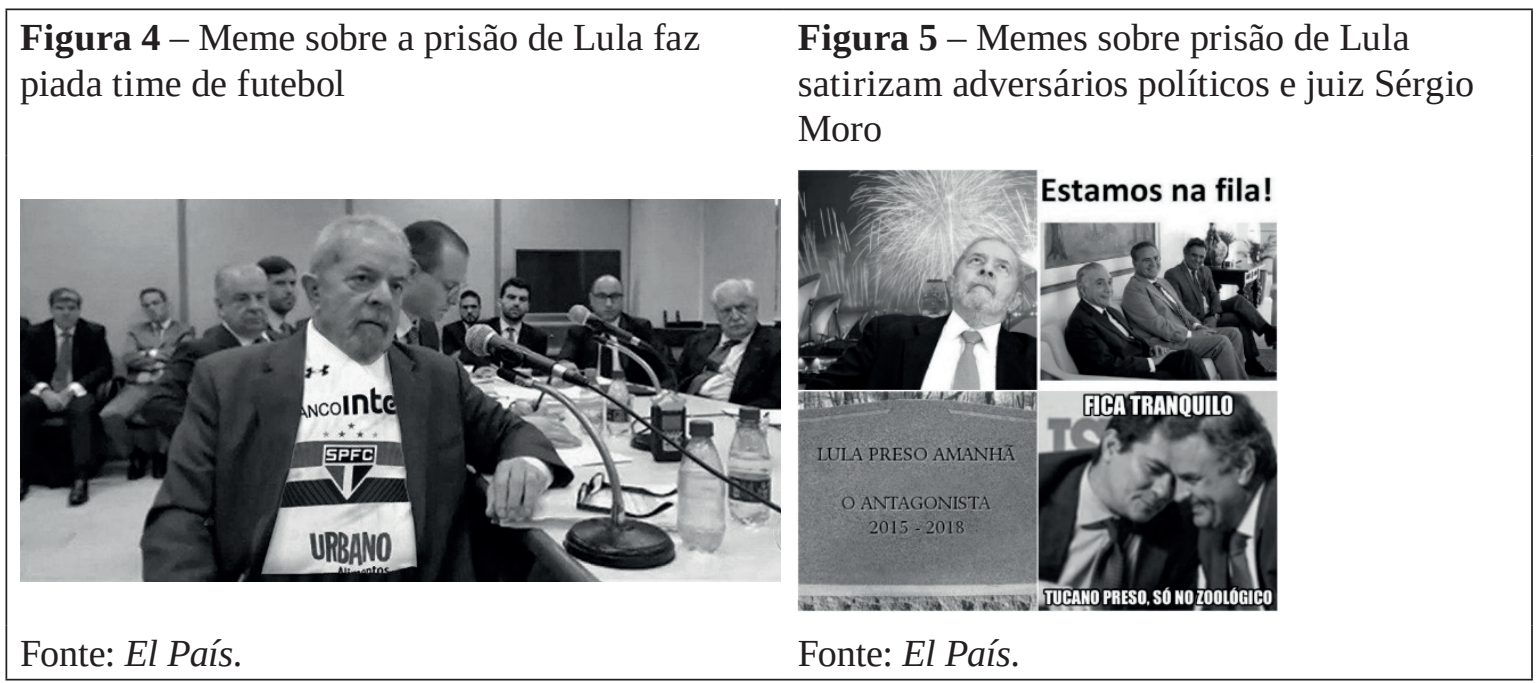

Fonte: autores.

A segunda imagem da lista de memes apresentada pelo El País é um compilado de quatro memes que desviam igualmente a crítica da figura de Lula, alternando entre as subcategorias dos memes de discussão pública de piadas situacionais e alusões literárias. No primeiro meme, uma costumeira alusão ao fuso horário australiano antecipa a prisão de Lula e, logo abaixo, a lápide do meme "Lula Preso Amanhã” que nasceu de várias previsões equivocadas do site $O$ Antagonista que costumava divulgar um suposto furo da prisão do ex-presidente no dia seguinte - um humor brando, comedido que não compromete a simpatia pelo personagem principal. Na coluna subsequente, a legenda do meme “estamos na fila!” complementa o sentido da imagem de Michel Temer, Renan Calheiros e Aécio Neves, todos delatados e investigados pela Operação Lava Jato, sentados supostamente aguardando seus mandados de prisão. O meme logo abaixo, no entanto, evidencia que a espera é em vão, visto que a intimidade retratada na polêmica foto do juiz Sérgio Moro com expressão divertida e em conversa "ao pé do ouvido”, remetendo a intimidade, com Aécio Neves recebeu a legenda "Fica tranquilo, tucano preso só no zoológico”, insinuando a proteção do juiz ao PSDB e que a prisão de Lula está mais relacionada à perseguição política do que ao bom funcionamento das instâncias judiciárias no país.

Dado o tom da curadoria nos dois primeiros memes, o veículo traz em seguida mais três peças que omitem imagens visuais de personagens políticos, no entanto, duas fazem referência a Lula - a primeira ironiza seu suposto vício em bebida alcoólica, configurando o único meme da seleção com foco na piada sobre personagens da política; a segunda mostra apenas o personagem homônimo Lula Molusco sendo preso, sem legenda ou parágrafo interpretativo, concluindo a reportagem com mais uma alusão cultural e com um humor espiritual de crítica pouco acentuada. 
Já no site do Estadão, o assunto rendeu duas publicações no dia 8 de abril: uma galeria de imagens na editoria de política com o título "Veja memes após a prisão de Lula"; e outra no Blog Fausto Macedo, também na editoria de política, intitulada "Lula preso no meme"

Na galeria, os quatro primeiros memes elencados expõem a imagem do ex-presidente - o primeiro deles (Figura 8) ironiza simultaneamente a prisão e o fato do ex-presidente não ter cursado uma faculdade: “Passei na federal do Paraná. Estou indo pra lá...”, localizando o meme na subcategoria de piadas sobre personagens da política. O segundo meme da galeria, que está repetido na publicação do Blog Fausto Macedo, traz uma imagem de Lula sisudo, no carro da Polícia Federal entre dois agentes - apesar da legenda descontraída "quando vou viajar e não me deixam sentar na janela”, uma piada situacional, a imagem mostra um Lula pouco a vontade, sério e contrastante com aquele que, horas antes, era ovacionado por militantes de esquerda em São Bernardo do Campo-SP. O terceiro meme mostra Lula em uma sacada, semelhante à do Sindicato dos Metalúrgicos do ABC - onde ele estivera nos dois dias anteriores à sua prisão - falando ao telefone, com a seguinte legenda: "Alô? É da odebréchi? Ocêis faiz túnel?”. O semblante de preocupação, a semelhança de cenário e a legenda inferem um possível reconhecimento de derrota e uma última tentativa de escapar da prisão, além da recorrente piada sobre personagens da política que sugere o baixo nível de instrução formal do ex-presidente. O quarto meme dessa primeira parte da galeria é uma playlist do aplicativo Spotify de título "Lula Preso" com as seguintes faixas: Diário de um Detento, Folsom Prison Blues, Prisão particular e Jailhouse Rock. A foto de Lula na playlist é grotesca, na medida em que a posição de sua mão no rosto dá a impressão de que seu dedo amputado estaria completamente introduzido no nariz. A composição, assim como o compartilhamento deste meme, revela um prazer consequente da situação de vulnerabilidade do ex-presidente. A segunda parte da galeria não conta com a imagem de Lula, mas insiste na sátira, que expõe o lado negativo e vulnerável do personagem, próprio das piadas sobre personagens da política descritas por Chagas (2017), além de enaltecer a atuação do juiz Sérgio Moro em um meme que faz referência ao jogo Mortal Kombat sugestionando um confronto entre o juiz e políticos investigados na Lava Jato, determinando que Moro sai como vencedor em todos os embates.

Disponível em: http://politica.estadao.com.br/galerias/geral,veja-memes-apos-a-prisao-de-lula,36426. Acesso em: 4 jun. 2018.

Disponível em: http://politica.estadao.com.br/blogs/fausto-macedo/lula-preso-no-meme/. Acesso em: 4 jun. 2018. 
Quadro 4 - Memes da galeria do Estadão

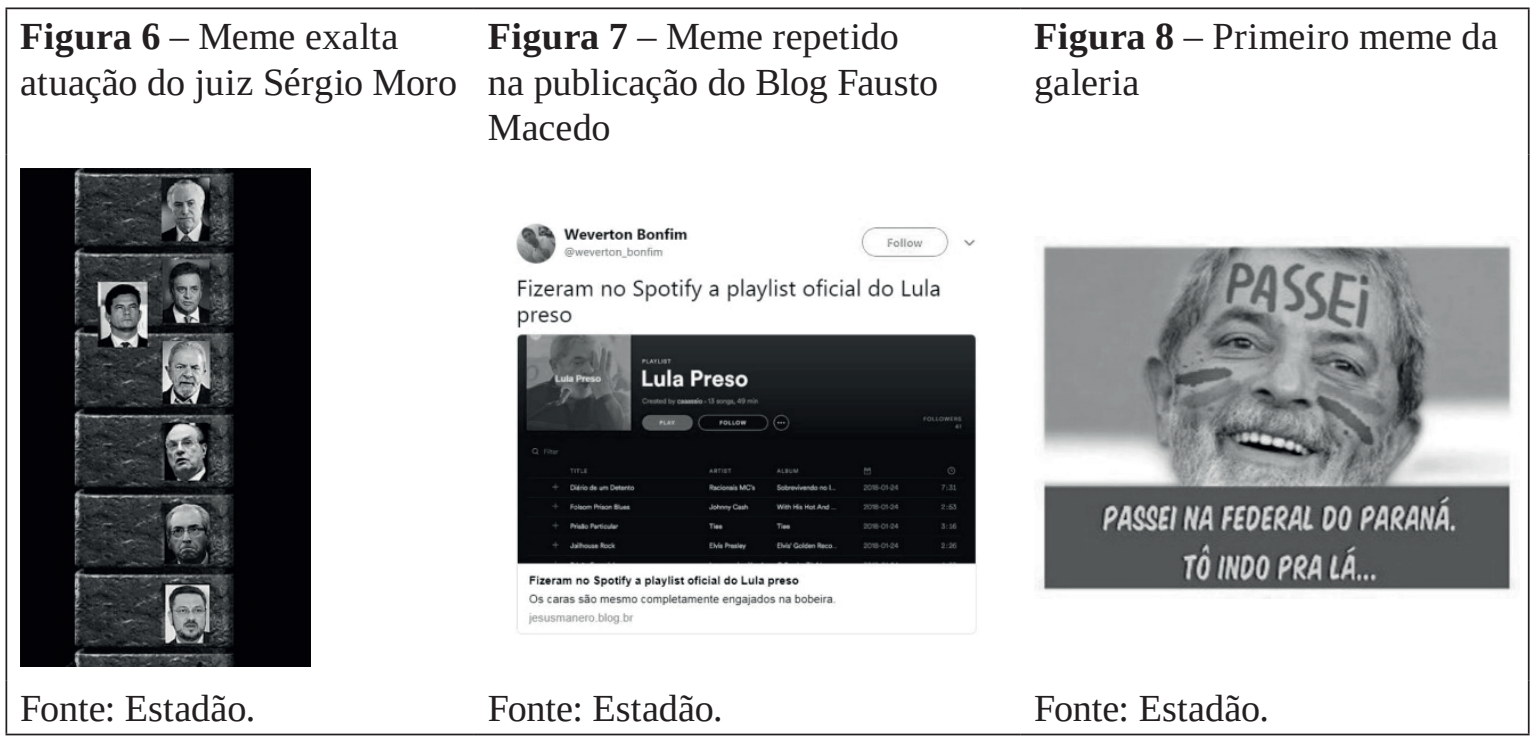

Fonte: autores.

No Blog Fausto Macedo, a seleção dos memes mescla peças de apoio e desaprovação à prisão do ex-presidente, porém, em proporção tendenciosa ao apoio. Dos oito memes selecionados, dois trazem a foto de Lula em meio aos manifestantes do ABC, horas antes de se entregar à Polícia Federal, com legendas que fazem referência ao polêmico slide apresentado pelo procurador da República, Deltan Dellagnol para explicar denúncia contra Lula; e outros três memes retratam Lula preso - no primeiro deles, uma montagem expõe o ex-presidente em situação de total vulnerabilidade, sugestionando fracasso, derrota. Lula aparece encarcerado em uma pequena cela com banheiro aberto, vaso sanitário rente ao chão e uma foto na parede com sua falecida esposa Marisa Letícia (Figura 9). A legenda faz referência ao reality show Big Brother Brasil da Rede Globo, à cobertura da prisão e ao Partido dos Trabalhadores representado pelo número 13. A representação de Lula preso é repetida em outras três imagens - em uma delas, a justaposição de fotos da sua prisão em abril de 1980 e abril de 2018 com marca d’água do grupo Direita São Paulo.

O personagem Lula Molusco do desenho animado Bob Esponja aparece em duas das três publicações, amenizando o tom do chiste. A referência ao desenho nos remete novamente à segunda subcategoria dos memes de discussão pública proposta por Viktor Chagas: alusões literárias ou culturais. A exceção é a galeria da editoria de política do Estadão que, no geral, carrega as críticas mais acentuadas. Outra subcategoria marcante nas publicações é a de piadas sobre personagens da política que destacam, como vimos a figura de Lula, Sérgio Moro, Michel Temer, Aécio Neves e outras personalidades investigadas por corrupção. 
Quadro 5 - Memes do Blog Fausto Macedo/Estadão

\begin{tabular}{|c|c|c|}
\hline $\begin{array}{l}\text { Figura } 9 \text { - Primeiro meme da } \\
\text { matéria: montagem mostra o } \\
\text { ex-presidente encarcerado }\end{array}$ & $\begin{array}{l}\text { Figura } 10 \text { - Meme com } \\
\text { imagem de Lula em custódia } \\
\text { da Polícia Federal a caminho } \\
\text { de Curitiba }\end{array}$ & $\begin{array}{l}\text { Figura } \mathbf{1 1} \text { - Último meme } \\
\text { da matéria mostra Lula preso } \\
\text { mais uma vez }\end{array}$ \\
\hline (2) carlosopressor & dimitri peralta & itoriotneto \\
\hline $\begin{array}{l}\text { Assine já o pacote Pay-per-view e } \\
\text { tenha acesso } 24 \text { horas a CELA mais } \\
\text { vigiada do Brasil. Apenas } 13 \text { Reais. }\end{array}$ & $\begin{array}{l}\text { quando eu vou viajar e não me } \\
\text { deixam sentar na janela }\end{array}$ & \\
\hline $\begin{array}{l}\text { Fonte: Blog Fausto Macedo/ } \\
\text { Estadão. }\end{array}$ & $\begin{array}{l}\text { Fonte: Blog Fausto Macedo/ } \\
\text { Estadão. }\end{array}$ & $\begin{array}{l}\text { Fonte: Blog Fausto Macedo/ } \\
\text { Estadão. }\end{array}$ \\
\hline
\end{tabular}

Fonte: autores.

\section{Considerações finais}

A presença da mídia no processo de replicação dos memes de discussão pública reforça a avaliação tanto de Habermas (2003) quanto de Rawls (1999) sobre uma esfera pública com circulação de agenda "impura", pautada a partir da visibilidade proporcionada pela mídia e não por uma "seleção natural” dos assuntos pertinentes ao bom funcionamento das instituições políticas e ao bem-estar social. Os assuntos meticulosamente selecionados e tratados pelos meios de comunicação invadem a esfera pública com objetivos claros, como pudemos observar nas publicações tendenciosas sob o manto de neutralidade do humor e do entretenimento dos memes.

Temos então que a comprovada penetração dos memes na agenda pública reconfigurando discursos hegemônicos na sociedade, que nós pensamos inicialmente como fonte de resistência se comprova finalmente como uma força inicial de resistência, mas se consolida como instrumento de mobilização social - para o bem ou para o mal. Por mais que se ambicione desqualificar políticas e personalidades na produção de um meme, é seu potencial de replicabilidade que determina seu sucesso e faz com que instâncias políticas sejam atingidas.

Nesse sentido, poderíamos inferir que os produtores de memes não estão sozinhos nessa mobilização, pois, como comprovamos, a mídia hegemônica também faz uso das táticas meméticas ao promover a curadoria de um conjunto de produções que replica, e desse 
modo se posiciona e fortalece sua atuação na esfera pública dando visibilidade à agenda que lhe convém, ainda que por vezes haja a inclusão de memes de posicionamento crítico contrário à linha editorial dos veículos, num simulacro de imparcialidade. Também por isso, não podemos falar simplesmente em resistência, pois os memes atravessam um processo de transgressão, mas também de cooptação até atingirem a visibilidade necessária para a formação de uma Opinião Pública.

É importante destacar que, por meio da metodologia utilizada, não pudemos avaliar o grau de discutibilidade que esses memes, assim como as notícias sobre eles, são capazes de promover. Apesar de não ter sido este nosso objetivo em nenhum momento, consideramos relevante reforçar que a formação da Opinião Pública, conforme preconizada por Habermas (2003) em seu ideal de democracia deliberativa, não pôde ser mensurada aqui e, portanto, não podemos inferir que a atuação dos memes nesse processo é capaz de movimentar as duas etapas necessárias para a tomada de decisões institucionais democraticamente ideais - esfera pública, com a visibilidade e a opinião pública, com a discutibilidade.

É preocupante observar que, em tempos de grave crise política, no país, nossa Opinião Pública seja construída com tão pouco rigor e pautada levianamente pela circulação massiva de informações com alto poder de replicabilidade. É preocupante, sobretudo, quando observamos que esse critério pode influenciar deliberações públicas de interesse social. Vislumbramos um cenário arriscado de uma governabilidade vulnerável à Opinião Pública - o que seria louvável em condições ideais de discutibilidade - formada por quantidade em detrimento do conteúdo e da reflexão. No momento em que concluímos este trabalho, políticas públicas essenciais são discutidas com base na "vontade pública” fomentada por fake news, correntes digitais e conteúdos diversos produzidos anonimamente sem critérios transparentes de confiabilidade.

Enquanto na década de 1970, o humor de resistência serviu aos brasileiros para a formação de uma consciência crítica e denúncia das arbitrariedades do regime militar, talvez as novas possibilidades tecnológicas de produção de conteúdo por parte dos usuários na Era Digital nos leve para um caminho diferente, em que a democracia seja ironicamente ameaçada pela livre e paritária circulação de pensamentos nessa esfera pública de tanta visibilidade e ainda não mensurada discutibilidade.

A presente investigação de forma alguma nega nossa proposta anterior de uma compreensão do processo de contaminação midiática pelos memes por meio da Semiótica da Cultura, pelo contrário: reforça a premissa do continuum semiótico e da construção dialética constante que se estabelece nas áreas de tensão entre núcleo e periferias da semiosfera. Tampouco esgotamos aqui as análises das condições de produção, dos símbolos e significados do nosso corpus, assim como as intenções do narrador, que ressignifica os discursos construídos nas redes sociais e os expõe em novo contexto direcionando seus sentidos. Trata-se, aqui, de uma proposta de reflexão que consideramos essencial para a compreensão da ecologia da mídia contemporânea, o alcance dessa produção imensurada no 
ciberespaço e suas possibilidades de cooptação e influência - consciente ou não, no debate político de um Brasil em crise.

\section{Referências}

BRAndẽO, H. H. N. Analisando o discurso. Museu da Língua Portuguesa. Disponível em: https:// museudalinguaportuguesa.org.br/wp-content/uploads/2017/09/Analisando-o-discurso.pdf. Acesso em: 10 set. 2020.

CASTELLS, M. Redes de indignação e esperança: movimentos sociais na era da internet. Rio de Janeiro: Zahar, 2013. $271 \mathrm{p}$.

CHAGAS, V. et al. A política dos memes e os memes da política: proposta metodológica de análise de conteúdo de memes dos debates eleitorais de 2014. Revista Intexto, Porto Alegre, n. 38, jan./abr. 2017, p. 173-196. Disponível em: http://seer.ufrgs.br/index.php/intexto/article/view/63892. Acesso em: 10 out. 2017.

CHAGAS, V.; TOTH, J. Monitorando memes em mídias sociais. In: SILVA, T.; STABILE, M. (Orgs.). Monitoramento e pesquisa em mídias sociais: metodologias, aplicações e inovações. São Paulo: IBPAD, 2016. Disponível em: https://www.ibpad.com.br/o-que-fazemos/publicacoes/monitoramento-e-pesquisa-emmidias-sociais-metodologias-aplicacoes-e-inovacoes/. Acesso em: 10 out. 2017.

DAWKINS, R. O gene egoísta. Tradução: Geraldo H. M. Florsheim. São Paulo: Itatiaia/EDUSP, 1979.

HABERMAS, J. Direito e democracia: entre facticidade e validade. v. 1. Rio de Janeiro: Tempo Brasileiro, 2003.

LÓTMAN, I. M. La semiosfera I: semiótica de la cultura y del texto. Tradução de Desiderio Navarro. Valência: Frónesis Cátedra, 1996.

LULA preso, memes à solta. El País, São Paulo, 07 abr. 2018. Brasil. Disponível em: https://brasil.elpais.com/ brasil/2018/04/06/politica/1523046165_909738.html. Acesso em: 4 jun. 2018.

MACEDO, F.; VASSALO, L. Lula preso no meme. Estadão. São Paulo, 8 abr. 2018. Política. Disponível em: http://politica.estadao.com.br/blogs/fausto-macedo/lula-preso-no-meme/. Acesso em: 4 jun. 2018.

MILNER, R. The world made meme: public conversations and participatory media. Cambridge: MIT Press, 2016. E-book.

RABATEL, A. Homo Narrans: por uma abordagem enunciativa e interacionista da narrativa: pontos de vista e lógica da narração teoria e análise. v. 1. São Paulo: Cortez, 2016. p. 15-55.

RAWLS, J. A Theory of Justice. Harvard University Press, 1999.

SHIFMAN, L. Memes in digital culture. Cambridge: MIT Press, 2014.

SILVA, S. A. B. da. Estética utilitária: interação através da experiência sensível com a publicidade. João Pessoa: UFPB, 2010.

SOUZA, T. A. Memes e contracultura: a reconfiguração de narrativas hegemônicas na semiosfera. Revista Temática, Paraíba, ano XVIII, n. 12, dez. 2017, p. 51-64. Disponível em: http://www.periodicos.ufpb.br/ojs2/ index.php/tematica/article/view/37588. Acesso em: 4 jun. 2018.

SOUZA, T. A. Os memes em pauta: relações com a mídia mainstream no ideal habermasiano de democracia deliberativa. 2019. 130 f. Dissertação (Mestrado em Comunicação Social) - Universidade Metodista de São Paulo, São Bernardo do Campo. 
VEJA memes após a prisão de Lula. Estadão, São Paulo, 08 abr. 2018. Política. Disponível em: http://politica. estadao.com.br/galerias/geral,veja-memes-apos-a-prisao-de-lula,36426. Acesso em: 4 jun. 2018.

\section{Tássia Aguiar de Souza}

Coordenadora da Assessoria de Comunicação na Secretaria de Estado dos Direitos Humanos e Participação Popular do Maranhão. Mestre em Comunicação Social pela Universidade Metodista de São Paulo. Especialista em Marketing pela Fundação Getúlio Vargas e graduada em Jornalismo pela Universidade Federal do Maranhão. E-mail: tassiaguiar@gmail.com

\section{Mateus Yuri Passos}

Professor do Programa de Pós-Graduação em Comunicação Social da Universidade Metodista de São Paulo e editor da revista Comunicação \& Sociedade. Doutor em Teoria e História Literária pela Unicamp. Líder do grupo de pesquisa CENA (Comunicação, Enunciação e Narrativas). Integra a coordenação da rede de pesquisa Narrativas Midiáticas Contemporâneas (RENAMI/SBPJor). E-mail: mateus.passos@metodista.br.

Recebido em: 30.05.2019

Aprovado em: 29.11.2020

Este artigo é publicado em acesso aberto (Open Access) sob a licença Creative Commons Attribution Non-Commercial (CC-BY-NC), que permite uso, distribuição e reprodução em qualquer meio, sem restrições, desde que sem fins comerciais e que o trabalho original seja corretamente citado. 